はほとんよ゙この方法で調製できる. 例えば, 高温超伝導 酸化物の原料であるイットリア $\left(\mathrm{Y}_{2} \mathrm{O}_{3}\right)$ の広表面積試料 も短時間に調製可能である. 金属酸化物調製のデータを 表 2 に示す. この実験結果は, マイクロ波の持つ加熱効 率の高さを如実に物語っている.

\section{3. 小型プラズマ発生装置の開発}

プラズマ発生装置は概して高価であり,なおかつ図体 の大きいものが多い. その為, 限られたスペースの実験 室に設置する時に苦労する．もっと安価で手軽に使える 実験室サイズのプラズマ発生装置の出現が望まれる.

こうした状況のもとで, 筆者らの主幸するプラズマ化 学フォーラムの会員の中から化学者向けの新しいプラズ

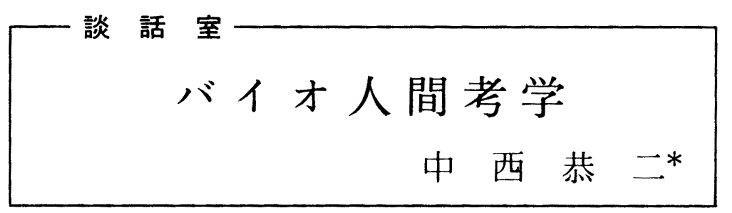

〔その1〕古代ローマ帝国に代表される奴隷社会は， いわば一大バイオテクノロジー社会であったといえる. ある時はロボットとして, ある時はバイオセンサーとし て,またある時は人工知脳として現代社会とほとんど変 わらぬ人間を道具に使っていた。現在ヨーロッパでは人 件費削減のため低賃金の外国人労働者を大量に雇い入れ ている.日本があし外国人労働者受け入れに先鞭をつけ ていたとしたら, 現在のヨーロッパのようにすんなりと 世界に受け入れられていただろうか。奴隷社会の再来な どといった日本叨きが聞てえてきそうだ。

最近日本人が, 臓器移殖の手術を受けに, 東南アジア へ出かけることが人道的に問題となっている. 一方, 過 疎地農村の男性がスリランカの女性を妻として迎えたて とが話題となっている. どちらのケースも人間が物財化 してきた例であり, 社会的に問題が生じ得る可能性を孕 んでいる. 物財の移動に付随して文化も移す心配りを, 日本人はもっ之欧米に学ぶべきである．人間が移動する 場合, とくにその配慮が重要である.

〔その 2〕生物の中で脳の重さが一番重いのは, しろ ながすくじら, 生物の中で体重当りの脳の重さが一番重

* 川崎製鉄株式会社技術研究本部鉄鋼研究所プロセ 不研究部長 1988 年 8 月 15 日受理
マ発生装置を開発しようという機運が高まってきた。 そ して, 第 1 号機はマイクロ波プラズマ発生装置と決まっ た. 出力を $500 \mathrm{~W}$ 程度とし, マイクロ波の伝送にはア ルミニウム導波管を用いる. 小型マイクロ波発振器はす でに完成した. 現在, アイソレータ, パワーモニター, インピーダンス調整器の小型一体化に取りくんでいる. 関心をお持ちの方はプラズマ化学フォーラム事務局(電 話 03(496)5491, 事務局員 : 水上) までで連絡下さい.

\section{文献}

(1) K.Sugiyama, O.Nomura et al. : Plasma Chem. \& Plasma Process, 6(1986), 179.

（2）杉山和夫, 青木秀元他: 第 1 回プラズマ化学合同シンポ ジゥム予稿集, 東京, C-5(1988).

い生物は，はつかねずみだそうだ。じゃあ何故，人間は 地球を征服し得たのか。答はちゃんと，人間の名誉のた めに用意されていた．体表面積当りの脳の重さが最大の 生物が人間だそうだ。そういえば古代, 自然と生命の闘 いはすべて体表面への刺戟すなわち Surface force と して与えられた。氷河期の寒さしかり, 生物間の種族保 存の闘いまたしかりで，第 1 撃はまず表面に与えられた。 このような Surface force，言換えればストレスの世界 に最む適合する生物は，体表面積当りの情報処理能力に 優れた人類だったわけで，人類はストレスの中で生かさ れて来たことになる。

人工骨の話を聞いた。具合のよすぎる人工骨を埋めこ み, 本来の骨に応力がかからなくなると骨の溶出が進み, 最後は人工骨を残して溶けてしまうそうだ. 宇宙飛行士 は無重力下で骨がやせて皮還する。骨にしてみりゃ「お れは一体何なんだ」とすねてしまうのだろう，上述のよう にストレスあっての生命といえ, 社会の中で受けるスト レスは命の源泉であある，皆さん，拈客様や上司から受 けるストレスは有難いお薬ですぞ。だから可愛い部下に あ応分のストレスをかけてやらんと………

〔その 3〕さて，今後も人間が地球を征服しつつける だろうか．小生の推論は noである。地球圈の放射能は 着実に增加しており, 外界からの刺戟は生体の内部に直 接抢よんできている.てのような Body forceに対抗で きるのは，体積当りの情報処理能力に優れた生物である. 今後何十万年かして地球に生物がいるすれば，それは はつか栘ずみであろう。 